\title{
HISTORICAL ASPECT OF FORMATION OF INTERNATIONAL CUSTOMS RELATIONS OF UKRAINE WITH THE STATES OF THE WORLD
}

The article is devoted to the analysis of the historical stages of formation of international customs relations between Ukraine and other countries. The purpose of the article is a theoretical and legal analysis of the factors that, at different times, influenced on the development of Ukrainian customs cooperation with various countries worldwide.

Methods. The article uses a comparative legal method (which allows to systematize the main stages of customs cooperation); the method of analysis and synthesis (which helps to outline the basic principles and methods of international customs relations); and the method of generalization (which allows to draw conclusions from the analysis).

Results. The authors emphasizes that international customs cooperation directly determines the directions of international norms implementation into the customs legislation of Ukraine. The results of such implementation are very important for the formation of Ukrainian customs policy because they help to increase the protection level of country's customs interests and guarantee the rights of foreign economic entities. The article argues that the active development of customs cooperation begins with the Ukraine's independence. It is proved that the century-old history of customs international relations in Ukraine testifies to the constant evolution and improvement of not only the types of duties and categories of customs but approaches to the state customs policy. This also applies to the authorities' approaches to customs policy development, which have changed from imperative to more dispositive ones. It was established that the conditions for the formation of customs policy in Ukraine have always been difficult and affected the level of customs legislation integration into European standards of customs regulation.

Conclusions. It was found that the implementation of international norms into the customs legislation of Ukraine affects only the rules of procedural nature, i. e. the procedure for certain customs activities (customs control, customs clearance), and therefore does not affect the structure of customs authorities and their competence. Such conclusions were obtained due to a thorough analysis of certain historical stages of customs and customs cooperation development. We will talk about the following five stages of historical development, which are distinguished by specialists in the field of customs law: the period of Kyivan Rus, the period of the Cossack Hetmanate, the period of the Ukrainian People's Republic, the period of the USSR, the period of independent Ukraine.

Key words: foreign economic activity, customs legislation, customs affairs, international customs relations, customs relations, customs policy, formation and development.

JEL Classification: K23, K29, K33.

\section{Viktor FILATOV, \\ Associate Professor at the Department of Civil, Commercial and Environmental Law University of Customs and Finance, Candidate of Legal Sciences, Associate Professor filatov_viktor@ukr.net orcid.org/0000-0002-8059-3736}

\section{Serhii HERASYMCHUK,} Senior Lecturer at the Department of Civil, Commercial and Environmental Law

University of Customs and Finance, Candidate of Legal Sciences herasymchukss@gmail.com orcid.org/0000-0002-4038-3048

\section{Introduction}

The development of customs today is one of the priorities of the Ukrainian authorities, which seek to harmonize customs legislation and adapt it to the European model of customs regulation. A significant obstacle to this task is the lack of an effective state mechanism for the implementation of international norms into customs legislation. As a result, Ukraine is slow to adjust its customs legislation to European standards. By the way, such adaptation is an international obligation of our country, which is fixed in the norms of the EU-Ukraine Association Agreement. In addition, the need to implement international norms is due to the transition period in which Ukraine has been since 2014. This period necessitates a comprehensive reform of government institutions, including customs. It is also quite important to recognize systemic errors in the development of customs policy, which is the starting point for the 
development of foreign economic activity. The introduction of perfect implementation mechanisms is not possible without a comprehensive understanding of the history of international customs relations, which provides an insight of the main factors that have influenced the process of customs cooperation. Today, this problem, after radical changes in public policy in 2014, has hardly been studied, which is a significant problem for the theory of customs law.

\section{Analysis of recent research and publications}

The history of customs affairs and customs cooperation was studied by such scientists as A.A. Dubinina, L.V. Yerofeyenko, O.V. Morozov, Yu.V. Makogon, B.M. Novosad, S.M. Popova, P.V. Pashko, J.L. Rysich, S.V. Selezen, S.V. Sorokina, V.V Sergiyenko, V.B. Chornyi, R.B. Shyshka, A.B. Yatsenko and others. However, in the conditions of transition period and European integration, this topic does not lose its relevance, but, on the contrary, becomes a priority area of the scientific research. This is due to the need to introduce an effective mechanism for implementing international norms in the customs legislation of Ukraine.

\section{Presenting main material}

The excursion into the historical domain is essential in this research because it allows us to trace the evolution and influence of international norms on the development of customs affairs in our country, to find out what factors contributed to and negatively influenced the formation and development of international customs cooperation. The first information about the concept of "customs affairs" dates back to ancient times namely to III-II millennia BC. Historical documents attest to the existence of customs relations in countries such as Greece, Egypt, Byzantium, Babylon. The emergence of customs relations is directly related to the development of society's economy and the growth of trade between countries. Even then, internal and external trade spaces were created, thanks to which it was possible to simplify the procedure of trade between the countries as well as the introduction of customs tariffs. In our opinion, the most perfect customs system existed in the Ancient Rome. It gave us not only a developed customs law, but also a huge legal heritage, which formed the basis of the modern legal system. The main function of customs relations at that time was the fiscal function, the performance of which depended on the filling of the state treasury. On behalf of the state, it ensured the obligation to pay duties (Chornyi, 2000: 37).

Customs affairs in Ukraine have a long history too. Prerequisites for the emergence of customs relations in Ukraine are divided into two main groups. The first one includes economic factors in the appearance of customs relations, which subsisted in the growth of production, division of labor and the introduction of private property. The second one represent political factors, which determine the formation of the state, the emergence of law and state power. These preconditions stimulated the advent and development of customs relations in Ukraine. The history of customs affairs in Ukraine is categorized into five periods, which differ significantly from each other and have peculiar features. Specialists who study the history of Ukraine distinguish the following periods: the period of Kyivan Rus; the period of the Cossack Hetmanate; the period of the Ukrainian People's Republic (hereinafter - UPR); the period of the USSR; period of independent Ukraine. These historical periods will be studied separately (Filatov, 2013: 18).

\subsection{The period of Kyivan Rus}

The foreign trade activity of Kyivan Rus had its directions. One of them was trade with Scandinavia, to which iron ore was exported. Much attention was paid to trade with Italy and Byzantium, which imported furs and handicrafts to Kyivan Rus. The leading trading countries of the time were India, China and Persia, from which Kyivan Rus received silk, gold products and cattle. The countries of Western Europe also played an important role in the trade doctrine of Kyivan Rus. It exported weapons to these countries, and imported grain, honey and cattle. Kyivan Rus had many trade agreements with Byzantium, which, at that time, was the center of world trade. These agreements favored the state compared to other countries. In addition, the country participated in international customs agreements: Ostrog Customs Charter in 1288 and Regensburg Corporation in 1192. As early as 911, Prince Igor signed the agreement with Byzantium, which created favorable conditions for Kyivan Rus merchants. The purpose of these agreements was to simplify customs relations between trading partners and to study the experience of international customs regulations. The customs system of Kyivan Rus had its own structure, headed by Velykyi Kniaz (the Grand Prince of Kiev), and consisted of tax collectors, who were empowered to collect duties on behalf of the country. The protection of the customs border and forced collection of duties was performed by the druzhina (prince's armed forces). The structure of the customs system also included the boyars, who were the main payers of customs duties. The status of a boyar had to be earned. History confirms the existence 
of about two hundred types of duties in the times of Kyivan Rus, each of which had its own characteristics and applications. The main ones were travel, export and trade.

It must be noted that, in those days, customs significantly affected the economic situation in the country as a whole. The period of Kyivan Rus is the Golden Age in the history of Ukraine. This is a period of economic growth, development of international relations and the formation of the customs system that made it possible to effectively replenish the treasury by establishing simplified conditions for the movement of goods across the customs border (Chornyi, 2000: 48).

\subsection{The period of the Hetmanate}

The customs system of that period was based on world experience, and it did not have a single regulatory mechanism. All power was concentrated in the hands of the Hetman, and the duty went to the state treasury. The first step in the normative consolidation of customs regulation principles was the Constitution of Pylyp Orlyk (or Pacts and Constitutions of Rights and Freedoms of the Zaporizhian Host). This document raised the issue of the need for state regulation of customs relations. It must be recalled that Bohdan Khmelnytskyi established customs duties for goods imported into the territory of Ukraine in his Universal of 1654. The example from "Pacts and Constitutions of Rights and Freedoms of the Zaporizhzhian Host" given in B. Novosad's textbook "History of Customs and Customs Policy in Ukraine" testifies to the great attention of Cossack officers to customs. The analysis of this document allows us to state that the regulation of customs relations during the Hetmanate was carried out only on the principles of social justice (Rysich et al., 2000: 39).

At the beginning of the $18^{\text {th }}$ century, Ukraine was gradually losing its statehood and becoming dependent on Russia. L.V. Yerofeienko characterizes the state of affairs at that time as follows: few customs offices operating in those years on the territory of Ukraine were completely powerless (Yerofeienko et al., 2006: 47). After the defeat of the Zaporozhian Sich, Russia began the process of establishing full control over Ukraine that meant the liquidation of the Ukrainian customs system as an independent element. It was subordinated to Russia, which had a much more perfect customs system than the Ukrainian one. The process of gradual liquidation of the customs autonomy of Ukraine began in 1739 and consisted of certain stages. Initially, restrictions were imposed on the export of certain types of goods from Ukraine. Then, a ban on the import of alcoholic beverages from Poland was introduced. In 1764, the customs border of Ukraine was liquidated, and, ten years later, a manifesto on the abolition of the Hetmanate was issued. In 1724, Catherine I issued a decree on the patronizing customs tariff, which imposed a duty on goods imported into Russia so that Russian merchants could export goods without any obstacles.

Upon the initiative of Russia, customs districts were established on the territory of Ukraine: Rodzyvylivskyi, Skulianskyi, Izmailskyi, Odeskyi, Feodosiivskyi, Tahanrozkyi ta Sevastopolskyi. According to the structure, each district had four or five customs offices. In 1857, customs were divided into classes. First-class customs allowed the importation of non-prohibited foreign goods, and the duty was paid once a year. All duty-free goods were transported through the second-class customs. The term of customs clearance of such goods was two months. The third-class customs had a one-month period of goods clearance. In addition, the customs statute provided customs pledges and checkpoints. Customs policy in those years was chaotic. In 1822, there was a ban on the export of 21 types and the import of 300 types of goods. The establishment of the Department of Customs Duties as a part of the Ministry of Finance was an important event in 1864.

\subsection{The period of the Ukrainian People's Republic}

The period of the Ukrainian People's Republic (UPR) made a significant contribution to the development of the national customs system. At that time, in the early $20^{\text {th }}$ century, the south-western and southern customs districts were created. The Fourth Universal of January 22, 1918 proclaimed the formation of the UPR. One of the first steps of the authorities was the creation of the Department of Customs Duties and the Commission for the Organization of the Customs Service in Ukraine. Understanding the importance of customs, the state authorities made its development a priority of domestic policy. In 1918, an order was signed by the Minister of Finance of the UPR, which approved the procedure for collecting duties and the list of people responsible for establishing the country's customs service.

The customs office at that time was subordinated to the Ministry of Finance. The leading body was the Department of Customs Duties, which included customs agencies. According to their structure, the UPR customs was divided into two classes, which differed in the list of transported goods and the term of their customs clearance. Border guard corps, which had its own organizational structure, were also involved 
in the customs activities. In a short time of its existence, the UPR created its own customs system with certain units. In addition, the procedure for collecting customs duties was legally established as well as its types were outlined. Under pressure from the Soviet authorities in 1919, the UPR resigned. Ukraine became a part of the Soviet Union.

\subsection{The period of the USSR}

As R.B. Shyshka points out, during the years of the Soviet Union, Ukrainian customs officers gained a lot of experience (Shyshka, Serhiienko, 2004: 68), because the USSR was a powerful state with many international trade partners as well as the extensive experience in customs regulation. In 1922, the Customs and Tariff Committee was established within the People's Commissariat for Foreign Trade. Subsequently, customs was subordinated to the national economy. It was at this time that the first customs districts were established on the territory of Ukraine in Odesa, Kyiv and Kharkiv. In 1924, the Customs Charter was adopted, establishing the structure and basic principles of the customs system of the USSR. The management of this system belonged to the People's Commissariat for Foreign Trade.

The system of customs consisted of the Main Customs Department, the Customs Tariff Committee and territorial customs departments. As early as December 9, 1928, the USSR Customs Code came into force. The articles of this document established the rights and obligations of the subjects of customs relations, regulated the customs procedure and control, determined the list and amount of customs duties as well as the liability for violations of customs legislation. This is the first document that covered almost the entire field of customs relations, and it was valid for about forty years. In 1964, a decree of the Presidium of the Supreme Soviet of the USSR approved a new Customs Code. It took into account the latest trends in customs regulation and the needs of society. In the last year of the Soviet Union's existence, in 1991, a new USSR Customs Code was adopted (Melnyk et al., 2018: 5).

\subsection{The period of independent Ukraine}

In 1991, Ukraine became an independent state. This moment is considered to be the beginning of the formation of the modern customs system of Ukraine. The introduction of a market economy has led to a sharp increase in foreign economic activity in Ukraine. The state faced the issue of developing and implementing its own customs legislation, building the national customs system of Ukraine. Due to the lack of an effective customs policy, criminals intensified their activities in the direction of the illegal movement of goods across the state border. Historically valuable artifacts and other prohibited goods were exported from the country. As the result, smuggling volumes reached large levels (almost 29\%) and posed a significant threat to Ukraine's economy. It should be noted that during the years of independence, Ukraine, unfortunately, has not created a perfect legal framework to combat this type of crime. The state had to take the first step against crimes that encroach on the established procedure of moving goods across the state border. This step was the adoption of the Law of Ukraine "On Customs in Ukraine" and the Law of Ukraine "On the Implementation of the Customs Code of Ukraine" in 1991. They regularised the right of the state to independently form its own customs system and carry out customs affairs (Naidenko et al., 2018: 510).

The country's authorities pay a lot of attention to international cooperation in the field of customs. In 1992, Ukraine acceded to the Convention on establishing the Customs Cooperation Council (Council of Europe, 2005). Two years later, in 1994, an agreement "On Customs Cooperation" was signed between China and Ukraine (Cabinet of Ministers of Ukraine, 2010). Ukraine is constantly looking for partners in the field of customs regulation. For example, in 1999, the trade union of customs officers of Ukraine became a permanent member of a reputable trade union organization (PSI).

In 1996, in accordance with Art. 106 of the Constitution of Ukraine, the President of Ukraine issued the Decree "On the establishment of the State Customs Service of Ukraine on the basis of the State Customs Committee of Ukraine". The scientist A.A. Dubinina notes that this Decree created the conditions for the deep structural adjustment and reform of the customs system of Ukraine (Dubinina, Sorokina, 2004: 56). This document actually had a positive influence on the development of the national customs system of Ukraine. In 1997, tariff and cost departments were established in the structure of regional customs.

During the years of independence, the customs of Ukraine has reached a significant pace of development, proved by the increase in the quality indices of Ukrainian customs officers' work and the growth of the authority of customs bodies. It should be noted that these achievements became possible only due to the legislative work of the State Parliament and the implementation of modern management methods. The customs affairs in Ukraine is a component of the foreign policy of the state as a whole. According to 
Yu.V. Makohon, foreign economic contacts are a powerful factor in the social and economic progress of the society (Makohon, Yatsenko, 2005: 67). However, it should be said that these contacts affect the authority of the whole country. Since 1991, Ukraine has signed customs agreements with almost all CIS countries and other countries worldwide. Thus, international customs cooperation is conditioned by Ukraine's foreign policy. P.V. Pashko argues that customs affairs are one of the most important manifestations of state sovereignty (Pashko, 2008: 23). That is why it is important to provide a reliable and perfect mechanism for the implementation of international norms into the customs legislation of Ukraine.

\section{Conclusions}

Since the period of Kyivan Rus, wars, internal power disputes, territorial divisions, etc. have hampered the development and formation of customs relations in Ukraine. However, despite the difficulties, the customs affairs in Ukraine have always adopted foreign experience and moved in the direction of global trends in customs regulation. The independence has brought Ukraine freedom and autonomy in building its own customs system and developing customs policy. The purpose of international customs cooperation is to study the world experience in the field of customs regulation; simplify the procedure of customs control and clearance; search for partners to combat crimes related to violation of the established procedure of movement of goods, objects and vehicles. The process of intensifying international customs cooperation began in Soviet times, when the rule of national law prevailed. At present, international relations in the customs sphere are based on the same principle.

Thus, the implementation of international norms into the customs legislation of Ukraine covers only those norms of international law that do not contradict the Constitution of Ukraine. However, special attention must be paid to the state's foreign policy, namely the integration of Ukraine into the European Union, the prospect of accession to which requires the solution of such a task as the place of the European Union's acts in the domestic legal system. Today, Ukraine has considerable experience in the implementation of customs legislation. Nevertheless, there are some shortcomings, which do not allow considering its formation as a completed process. This is primarily due to the lack of a fixed order of international law implementation in the customs legislation of Ukraine, namely the lack of normative consolidation of the concept and its mechanisms. The excursion into the historical domain has also revealed that the implementation of international norms into the customs legislation of Ukraine can be attributed only to the rules of procedural nature, i. e. conducting certain customs activities (customs control, customs clearance), and, therefore, it does not affect the structure of customs authorities and their competence, which the government determines independently.

\section{References:}

1. Chornyi, V.B. (2000). Ukraina i mytna sprava: istorychnyi narys [Ukraine and customs: a historical essay]. Kyiv: KVIT, 349 p. [in Ukrainian].

2. Filatov, V.V. (2013). Implementatsiia mizhnarodnykh norm do mytnoho zakonodavstva Ukrainy: monohrafiia [Implementation of international norms to the customs legislation of Ukraine: monograph]. Donetsk: DonUEP, 201 p. [in Ukrainian].

3. Rysich, Y.L., Novosad, B.M., Morozov, O.V. (2000). Istoriia mytnoi spravy ta mytnoi polityky v Ukraini: navchalnyi posibnyk [History of customs and customs policy in Ukraine: tutorial]. Dnipropetrovsk: Akademiia mytnoi sluzhby Ukrainy, 68 p. [in Ukrainian].

4. Yerofeienko, L.V., Popova, S.M., Selezen, S.V. (2006). Mytne pravo: konspekt lektsii [Customs law: lecture notes]. Kharkiv: Simon Kuznets Kharkiv National University of Economics, 232 p. [in Ukrainian].

5. Shyshka, R.B., Serhiienko, V.V. (2004). Mytne pravo Ukrainy: pidruchnyk [Customs law of Ukraine: textbook]. Kharkiv: Espada, 351 p. [in Ukrainian].

6. Melnyk, O.H., Adamiv, M.Ye., Todoshchuk, A.V. (2018). Istoriia rozvytku mytnoi systemy Ukrainy: kliuchovi problemy ta zdobutky $\mathrm{v}$ umovakh yevropeiskoi intehratsii [History of development of the customs system of Ukraine: key problems and achievements in the conditions of European integration]. Ekonomika ta derzhava, no. 10, pp. 4-9 [in Ukrainian].

7. Naidenko, O.Ye., Yenina, A.O., Kostiana, O.V. (2018). Osnovni aspekty stanovlennia ta rozvytku mytnoi spravy v Ukraini [The main aspects of the formation and development of customs in Ukraine]. Hlobalni ta natsionalni problemy ekonomiky, no. 23, pp. 506-511 [in Ukrainian].

8. Council of Europe (2005). Pro stvorennia Rady mytnoho spivrobitnytstva: Konventsiia Rady Yevropy vid 15 hrudnia 1950 roku [About creation of Council of customs cooperation: Council of Europe Convention of 15 December 1950]. Ofitsiinyi visnyk Ukrainy, no. 12, pp. 313, art. 648 [in Ukrainian]. 
9. Cabinet of Ministers of Ukraine (2010). Pro vzaiemodopomohu u mytnykh spravakh: Uhoda mizh uriadom Ukrainy ta uriadom Kytaiskoi Narodnoi Respubliky vid 22 hrudnia 1997 roku [About mutual assistance in customs affairs: Agreement between the Government of Ukraine and the Government of the People's Republic of China of December 22, 1997]. Ofitsiinyi visnyk Ukrainy, no. 2, pp. 61, art. 80 [in Ukrainian].

10. Dubinina, A.A., Sorokina, S.V. (2004). Osnovy mytnoi spravy v Ukraini Fundamentals of customs in Ukraine]. Kyiv: ARS, 245 p. [in Ukrainian].

11. Makohon, Yu.V., Yatsenko, A.B. (2005). Mytna sprava: pidruchnyk [Customs business: textbook]. Donetsk: DNU, 341 p. [in Ukrainian].

12. Pashko, P.V. (2008). Osnovy mytnoi spravy Ukrainy: pidruchnyk [Fundamentals of customs affairs of Ukraine: textbook]. Kyiv: Znannia, 651 p. [in Ukrainian].

\title{
ІСТОРИЧНИЙ АСПЕКТ ФОРМУВАННЯ МІЖНАРОДНИХ МИТНИХ ЗВ'ЯЗКІВ УКРАЇНИ 3 КРАЇНАМИ СВІТУ
}

\author{
Віктор ФІЛАТОВ, \\ дочент кафедри цивільного, господарського та екологічного права \\ Університету митної справи та фінансів, \\ кандидат юридичних наук, дочент \\ filatov_viktor@ukr.net \\ orcid.org/0000-0002-8059-3736
}

Сергій ГЕРАСИМЧУК,

старший викладач кафедри ичиільного, господарського та екологічного права

Університету митної справи та фінансів,

кандидат юридичних наук

herasymchukss@gmail.com

orcid.org/0000-0002-4038-3048

Статтю присвячено аналізу історичних етапів формування міжнародних митних зв'язків України зі світовими державами. Метою статті є теоретико-правовий аналіз чинників, які в різні часи впливали на розбудову митного співробітництва Украӥни з державами світу.

Методи. Для написання статті використано порівняльно правовий метод (дає можливість систематизувати основні етапи розвитку митного співробітництва), метод аналізу та синтезу (дає змогу окреслити основні принципи й методи формування міжнародних митних зв'язків), а також метод узагальнення (дає можливість сформувати висновки з проведеного аналізу).

Результати. Автори акиентують увагу на тому, щзо міжнародне митне співробітництво безпосередньо визначає напрями прочесу імплементачії міжнародних норм до митного законодавства України. Результати такої імплементації дуже важливі для формування митної політики України, адже сприяють підвищенню рівня захисту митних інтересів країни та дають можливість гарантувати права суб'єктів зовнішньоекономічної діяльності. У статті аргументовано, що активний розвиток митного співробітничтва починається з моменту отримання Україною незалежності. Доведено, що багатовікова історія становлення митних міжнародних відносин України свідчить про постійну еволюиію та вдосконалення не лище видів мита та категорій митниць, а й підходів до митної політики держави. Це стосується підходів влади до розбудови митної політики, які змінювалися з імперативних на більш диспозитивні. Встановлено, щуо умови формування митної політики в Україні завжди були складними, що позначалося на рівні інтегрованості митного законодавства з європейськими стандартами митного регулювання.

Висновки. Вдалося з'ясувати, щчо імплементащія міжнародних норм у митне законодавство Украйни торкається лище норм процедурного характеру, тобто порядку проведення окремих митних процедур (митного контролю, митного оформлення), а отже, не впливає на структуру митних органів та питання ӥхньої компетенції. Такі висновки вдалося отримати завдяки трунтовному аналізу окремих історичних етапів розвитку митної справи та митного співробітництва. Ідеться про такі п'ять етапів історичного розвитку, які виокремлюють фахівиі в галузі митного права: період Київської Русі, період Гетьманшини, період Української Народної Республіки, період СРСР, період незалежної України.

Ключові слова: зовнішньоекономічна діяльність, митне законодавство, митна справа, міжнародні митні зв'язки, митні правовідносини, митна політика, становлення й розвиток. 